\section{Confucianism oversimplified}

SIR - Your leading article "Can Confucius excuse poor creativity?" (Nature 384, 197; 1996) suggests that Confucian thoughts are partly to blame for lack of creativity in Korea. I believe that this oversimplifies Confucian ideas.

The original texts of Lùn Yŭ (Analects), Zhōng Yōng (The Great Mean) and Dà Xué (Great Learning) constitute the gist of Confucian philosophy. They are records of what Confucius said or did during his lifetime. His philosophy is not an authoritarian philosophy where new ideas are not accepted, nor did he believe in blind devotion to authority.

In Dà Xué, Confucius said: "The perfecting of knowledge depends on the investigating of things. If we wish to carry on knowledge to the utmost, we must investigate the principles of all things we come into contact with, for the intelligent mind of man is certainly formed to know, and there is not a simple thing in which its principles do not inhere. But so long as all principles are not investigated, man's knowledge is incomplete." (James Legge's translation, for this and for other quotations.)

And in Lùn Yŭ, it was recorded that "there are four things from which the Master was entirely free. He had no foregone conclusions, no arbitrary predetermination, no obstinacy and no egoism." This is not a scholar unwilling to accept new ideas; on the contrary, his ideas about investigation and knowledge are almost identical to what we would call 'the scientific method' today.

Nor is blind respect for authority part of what Confucius advocated. He allowed his students to have their way, even when this was against the traditions of their times. Zhōng Yōng recorded him as saying that "sincerity is the end and beginning of things. Without sincerity there would be nothing." And when it pertains to knowledge, Lùn Yŭ recorded him as saying: "[Shall I teach you what knowledge is?] When you know a thing, to hold that you know it; and when you do not know a thing, to allow that you do not know it - this is knowledge." That is intellectual honesty.

Confucian thought, or strictly speaking, the philosophy of Rú Jiā, although lacking the logical rigour of many Western philosophical ideas, is a self-consistent philosophical system. Over 25 centuries, this system of philosophy has probably influenced more people than any other. The three main proponents behind it are Confucius, Mencius and Xún Ž̃. Even during that time, one could already discern slight differences between these three philosophers. The system of thought evolved during the Han Dynasty (206 BC to AD 220) to be "polluted" by astrological ideas. During the past 2,000 years or so, the philosophy of Rú Jiā, either in territories inhabited by the Chinese or elsewhere, has been subject to reinterpretation, misinterpretation, mutilation, disfigurement and occasionally enrichment. The philosophy of Rú Jiä spread to Japan, Korea, Vietnam and other Asian countries, but each country adapted it to suit its own cultural background. The Confucian philosophy in Japan or Korea today is a far cry from the original ideas of this native of the Duchy of $L \check{u}$.

If people read only Lùn Yŭ and try to understand Confucius's original ideas, they will see that he was a gentle, learned man, filled with curiosity about the world around him, never failing to see beauty in nature, understanding the youth of his day, and always emphasizing truth and sincerity. The outward show of things was never as important to him as the inward feelings. He was not a person who would demand that his students bow to him. Although his ideas did not explicitly mention imaginative and creative thinking, he certainly did everything to encourage it.

In your last paragraph, you ask: "So how to boost scientific creativity?" Perhaps we should return to the original ideas of Confucius, to emphasize the importance of investigation in our acquisition of knowledge, to encourage intellectual honesty and to avoid the four enemies of scholarly work of any kind: foregone conclusions, arbitrary predetermination, obstinacy and egoism.

At a time when people are uncovering more and more cases of scientific misconduct, Confucian standards of sincerity and intellectual honesty would be our best guardians against "dubious science" of any kind.

\section{P.-L. Chau}

Kemisk Laboratorium III,

H. C. Ørsted Institutet,

København Universitet,

DK-2100 København Ø, Denmark

e-mail: chau@st.ki.ku.dk

W. Y. Chau

30/74 Wardell Road,

Sydney 2206,

Australia

\section{Bias in Japanese university awards?}

SIR - I welcome the report ${ }^{1}$ of the new scheme, "Research for the Future", which has been set up this year with an initial budget of US $\$ 100$ million from the Japanese Ministry of Education to promote university-based research in Japan. It is particularly good news that these grants can be used flexibly to employ research workers. This is an important development, because traditionally all grants (including those from the government) have been limited to the purchase of hard- ware such as laboratory equipment, and have not been available for salaries.

It may, however, surprise readers, especially those from the West, that these project grants will be distributed in a 'topdown' fashion by a hierarchy of committees. Naturally, this may lead to suspicion of bias in the selection of project leaders, and this is referred to in the report. In the West, investigator-initiated peer-review has proved to be a successful system of grant allocation $^{2}$. Furthermore, this is the only system that allows "grant applications to be approved on the basis of scientific merit, rather than to meet an administrative or political agenda" 3 . Perhaps a lesson can be learned from Italy, where the administration of an AIDS research programme has successfully introduced a system of grant appraisal based on peer review by Italian and foreign scientists ${ }^{3}$.

Transparency or disclosure ('Kaiji' in Japanese) of the administrative process at all stages is increasingly demanded by the public in Japan. Taxpayers demand value for money in all areas, and the allocation of scientific funding is no exception. It would therefore also be wise to have a system for monitoring the productivity of grant recipients, as do established grant-awarding organizations in Western countries ${ }^{2}$.

\section{Noriyoshi Takei}

Institute of Psychiatry \& King's College

School of Medicine,

De Crespigny Park,

London SE5 8AF, UK

e-mail: spjunot@iop.bpmf.ac.uk

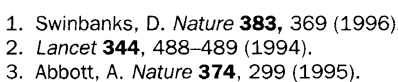

\section{Italian grants}

SIR - Alison Abbott says (Nature 383, 567; 1996) that in Italy "many grant-giving agencies and charities distribute small amounts of money evenly, to avoid upsetting unsuccessful applicants".

Italy invests only $1.1 \%$ of gross domestic product in scientific research, and most of this money is allocated for targeted projects, usually without peer review, to a minority of scientists. A negligible amount is available for basic research, where there is a huge number of applications. But even then the distribution is not even. In 1996, for example, the biomedical committee of the National Research Council distributed an average of US $\$ 8,000$ to only $22 \%$ of applicants. Private institutions such as Telethon use peer review by international referees. The distribution is not widespread, and it is a much more satisfactory system.

\section{Piergiorgio Strata}

Università di Torino,

Dipartimento di Neuroscienze,

C.so Raffaello 30 ,

I-10125 Torino, Italy 